\title{
The Effect of Hydrocortisone, Thyroxine, and Phenobarbital on Diamine Oxidase Activity in Newborn Rat Intestine
}

\author{
W. B. KARP, A. F. ROBERTSON, AND W. P. KANTO, JR. \\ Department of Pediatrics, Section of Neonatology, Medical College of Georgia, Augusta, Georgia 30912
}

\begin{abstract}
There is a reported association between administration of prenatal glucocorticoids and a decreased incidence of necrotizing enterocolitis in human infants. In rats, the degree of ischemic bowel disease correlates negatively with intestinal diamine oxidase (E.C. 1.4.3.6) activity. Since the administration of hydrocortisone, thyroxine, or phenobarbital to newborn rat pups affects the development of intestinal enzymes, we were interested in knowing whether hydrocortisone, thyroxine, or phenobarbital specifically affect intestinal diamine oxidase activity. We injected rat pups with hydrocortisone sodium succinate, lthyroxine pentahydrate, sodium salt, sodium phenobarbital, or the control solution on days $4,6,8$, or 10 of life (phenobarbital, days $3,5,7$, or 9). Pups were injected 3 days consecutively (phenobarbital, 4 days), and all were sacrificed on days $7,9,11$, and 13. Intestinal diamine oxidase and intestinal invertase (E.C. 3.2.1.26) activities were measured. Invertase was used as a control enzyme because it is known to be induced by glucocorticoid hormones. We found that the hydrocortisone-injected pups had 10-fold higher specific activity of invertase than the saline-injected animals. Diamine oxidase activity was significantly higher in the group receiving hydrocortisone and sacrificed on days 7, 9, and 11. Enzyme activity in both the hydrocortisone-injected and saline-injected groups was equal on day 13, as was enzyme activity on all days in the thyroxine-injected and sodium hydroxide-injected groups, and the phenobarbital-injected and the saline-injected groups. Our results suggest that diamine oxidase activity may be induced by hydrocortisone, but is not affected by thyroxine or phenobarbital. (Pediatr Res 21: 368-370, 1987)
\end{abstract}

The pathological changes in necrotizing enterocolitis in premature infants suggest ischemic damage as a possible etiological mechanism (1). In experimental animals the degree of ischemic bowel disease varies with the level of activity of diamine oxidase (E.C. 1.4.3.6) in intestinal tissue (2), implying that this enzyme may protect the intestine from the damage of ischemic insult. Human studies reveal that administration of prenatal glucocorticoid hormones decrease the incidence of necrotizing enterocolitis (3). These findings suggested to us that the protective effect of glucocorticoids might be due to early induction of the diamine oxidase. This study was performed to assess the effect of hydrocortisone and other substances known to affect intestinal devel-

Received July 9, 1986; accepted November 17, 1986

Address correspondence and reprint requests to W. B. Karp, Ph.D., D.M.D. BG 114, Department of Pediatrics, Medical College of Georgia, Augusta, GA 30912 . opment, thyroxine $(4,5)$, and phenobarbital $(6)$ on the activity of diamine oxidase in newborn rat intestine.

\section{METHODS}

Animals. Pups born to two, timed-pregnant Sprague-Dawley rats (Harlan Sprague-Dawley, Inc., Indianapolis, IN) were culled to eight per litter on day 1 (day of delivery $=$ day 0 ), randomly assigned without replacement to either an experimental group or control group and randomly returned to either of the dams, eight per dam. Pups were injected subcutaneously with either hydrocortisone sodium succinate, $50 \mathrm{mg} / \mathrm{kg}$ in $0.9 \% \mathrm{NaCl}$, 1-thyroxine pentahydrate, sodium salt, $0.5 \mathrm{mg} / \mathrm{kg}$ in $0.01 \mathrm{~N} \mathrm{NaOH}$ (both from Sigma Chemical Co., St. Louis, MO), sodium phenobarbital, $40 \mathrm{mg} / \mathrm{kg}$ in $0.9 \% \mathrm{NaCl}$ (Elkins-Sinn, Inc., Cherry Hill, NJ), $0.9 \% \mathrm{NaCl}$, or $0.01 \mathrm{~N} \mathrm{NaOH}$. The animals were injected once each day for 3 days (phenobarbital, 4 days) beginning on either days $4,6,8$, or 10 (phenobarbital, $3,5,7$, or 9 days). All pups were sacrificed by decapitation on days $7,9,11$, or 13 , respectively. The abdominal cavity was opened, the entire intestine from the pylorus to the rectum was removed quickly, and the intestinal tissue was placed on a glass plate on ice. All subsequent procedures were performed at $0-4^{\circ} \mathrm{C}$. The small intestine was identified as that portion of the intestine between the pylorus and the ileocecal junction. The small intestine was divided into thirds; the distal third (7) was assayed for diamine oxidase activity, the middle third (8) was assayed for invertase activity and the proximal third was discarded.

Diamine oxidase assay. The intestinal lumen was cleaned by perfusing with $0.9 \% \mathrm{NaCl}$, the tissue quickly blotted, weighed, and homogenized 10 times in 1:8 (w/v) $0.2 \mathrm{M}$ phosphate buffer, $\mathrm{pH} 7.6$, using a Potter-Elvehjm homogenizer. The homogenate was centrifuged at $30,000 \times g$ for $30 \mathrm{~min}$ and the supernatant assayed for diamine oxidase activity. The assay is essentially that described by Kusche and Lorenz $(9) .\left(1,4-{ }^{14} \mathrm{C}\right)$ Putrescine hydrochloride (S.A. $=100-200 \mathrm{mCi} / \mathrm{mmol}$ ) was obtained from Amersham/Searle, Arlington Heights, IL. Because $\delta$-pyrroline is thought to be a minor product of putrescine metabolism in tissues (10), we assured that in our assay system we used ideal conditions of incubation time and protein and substrate concentrations. All assays were run at two protein concentrations in duplicate and the results were averaged. Counting efficiency was $95 \%$, determined by adding C14-toluene as an internal standard. The specific activity of diamine oxidase was expressed as picomoles of extraction product formed per min per mg protein.

Invertase assay. Invertase (E.C. 3.2.1.26) was used as a control enzyme since it is known to be induced by hydrocortisone (11). The middle third of the small intestine was cleaned of debris, blotted, weighed, and homogenized 15 times in a loose-fitting Potter-Elvehjm device in 1:40 (w/v) $0.9 \% \mathrm{NaCl}$. The whole homogenate was frozen at $-20^{\circ} \mathrm{C}$ and analyzed within 3 days of preparation. On the day of analysis, the homogenate was thawed 
and rehomogenized five times. The preparation of the homogenates and the determination of invertase activity was a modification of the method of Dahlquist (12). Enzyme activity was determined under optimal conditions of time, protein, and substrate concentrations. The specific activity of invertase is expressed as nmoles glucose formed per min per mg protein.

Protein assay. Protein was determined on the $30,000 \times g$ supernatants (diamine oxidase assay) and on the whole homogenates (invertase assay) using the Lowry method (13). The whole homogenate was rehomogenized 20 times before analysis using a tight-fitting Potter-Elvehjm device.

Statistics. Significant differences between the drug-injected and sham-injected rats were determined using the unpaired Student's $t$ test.

\section{RESULTS}

Table 1 shows the effect of 3 days of hydrocortisone administration on intestinal invertase specific activity. Beginning at 4,6 , 8 , or 10 days of age, hydrocortisone administration produced a 40-fold increase in invertase specific activity, compared to the injection of $0.9 \% \mathrm{NaCl}$. Overall mean invertase activity in the saline-injected rats was $0.9 \mathrm{nmol} / \mathrm{min} / \mathrm{mg}$ protein; in the hydrocortisone-injected group, the overall mean was $36.7 \mathrm{nmol} / \mathrm{min} /$ mg protein.

In Figure $1, A$ presents the results of the effect of hydrocortisone on intestinal diamine oxidase specific activity. Diamine oxidase activity was significantly increased in the hydrocortisoneinjected animals compared to the saline-injected group when injections were begun on 4,6 , and 8 days of life $(p<0.002)$. When injections were begun on day 10 , there was no significant difference between the diamine oxidase specific activity of the saline-injected and cortisone-injected groups. The mean percent increase in diamine oxidase activity in the hydrocortisone-injected compared to the saline-injected animals was $38 \%$, this percent increase was approximately the same for each age group.

$B$ and $C$ show the results obtained with thyroxine and phenobarbital, respectively. The specific activity of diamine oxidase is the same in treatment and control groups at all sacrifice days. The apparent rise in diamine oxidase specific activity in both the phenobarbital treatment and control groups at day 9 probably reflects day-to-day variation in the assay as performed in our laboratory.

The only consistently significant differences in weight gain between experimental and control groups were in the hydrocortisone experiments. Animals receiving hydrocortisone showed significantly lower $(p<0.001)$ weight gains at all sacrifice days.

\section{DISCUSSION}

The present results show that diamine oxidase specific activity is increased in neonatal rat pups receiving hydrocortisone injections beginning at 4,6 , or 8 days of life. The overall $38 \%$ increase in diamine oxidase activity contrasts to the 40 -fold increase in

Table 1. Effect of hydrocortisone administration on the specific activity of intestinal invertase from neonatal rats*

\begin{tabular}{ccc}
\hline & \multicolumn{2}{c}{$\begin{array}{c}\text { Invertase specific activity } \\
\text { (mean } \pm \text { SD) }\end{array}$} \\
\cline { 2 - 3 } $\begin{array}{c}\text { Age at sacrifice } \\
\text { (days) }\end{array}$ & $0.9 \% \mathrm{NaCl}$ & Hydrocortisone \\
\hline 7 & $0.5 \pm 0.3$ & $30.1 \pm 5.4$ \\
9 & $0.6 \pm 0.2$ & $29.5 \pm 9.2$ \\
11 & $1.1 \pm 0.3$ & $40.2 \pm 18.4$ \\
13 & $1.4 \pm 0.5$ & $46.8 \pm 8.5$ \\
\hline
\end{tabular}

* Invertase specific activity $=$ nmol glucose formed $/ \mathrm{min} / \mathrm{mg}$ protein. Each mean represents the results from eight animals. Specific enzyme activity for each animal is the mean of duplicate analyses at two protein levels.
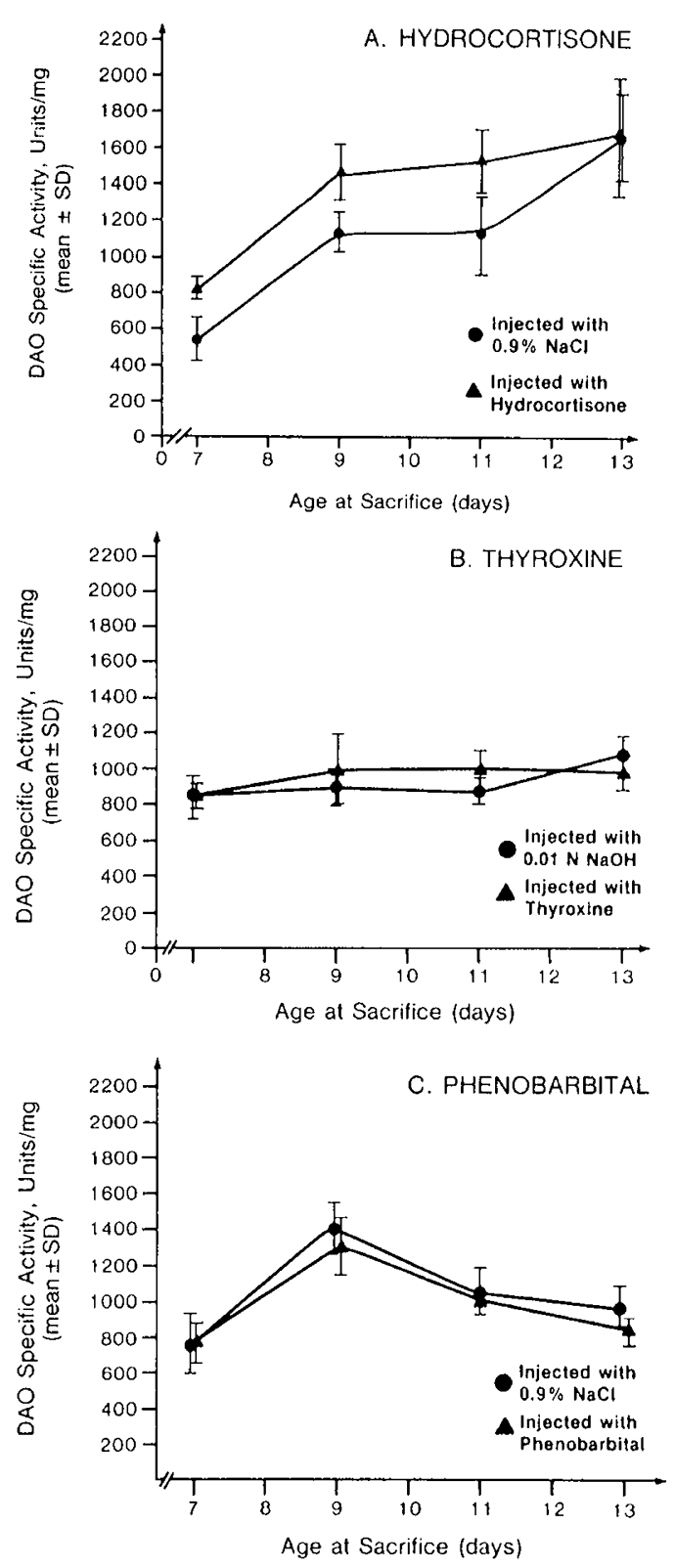

Fig. 1. The effect of hydrocortisone $(A)$, thyroxine $(B)$, and phenobarbital $(C)$ administration on the specific activity of intestinal diamine oxidase from neonatal rats. Diamine oxidase specific activity $=$ pmoles extraction product $/ \mathrm{min} / \mathrm{mg}$ protein. Each point on the graph represents the results from six to eight animals. Specific enzyme activity for each animal is the mean of duplicate analyses at two protein levels.

invertase specific activity measured in the same animals. Whether this increase in specific enzyme activity is caused by enzyme induction, activation, or other processes, is unknown. Also, the total diamine oxidase activity per animal in the hydrocortisone-treated and control groups may have been different due to less weight gain in the treatment group. Our experiments were not designed to measure this. Enzyme specific activity was not significantly different between thyroxine treatment and control groups and phenobarbital treatment and control groups on all sacrifice days.

An interesting clinical consideration is the question of a physiological relationship between diamine oxidase activity and the incidence of necrotizing enterocolitis. Present evidence in experimental animals suggests that histamine and intestinal diamine oxidase activity may play a role in ischemic bowel disease. Intestinal ischemia leads to histamine release, which, in the dog, 
may decrease mesenteric artery flow by as much as $64 \%$ (14). Pretreatment of animals with $\alpha$-aminoguanidine, an inhibitor of diamine oxidase, shortens the survival time of the animals after vascular occlusion of the superior mesenteric artery (15). Administration of the histamine-receptor antagonists, dimethylpyridine or cimetidine, reverses the shortening of survival time (2). Another factor that may account for increased intestinal histamine levels is the synthesis and release of histamine into the intestinal lumen by intestinal bacteria, specifically Clostridium perfringens (16). This is interesting because this organism is associated with an outbreak of necrotizing enterocolitis.

If the development of necrotizing enterocolitis is related to the ischemia-reperfusion cycle in the bowel of the premature infant, we would speculate that the development of diamine oxidase activity in the intestine could be protective. Clinical studies have shown that the severity of necrotizing enterocolitis is greater at lower postconceptive ages (17); the risk of this disease declines sharply at a postconceptive age of 35-36 wk (18). Also, the prenatal administration of dexamethasone to the mother decreases the incidence of necrotizing enterocolitis in the neonate (3). These data indicate that the risk of necrotizing enterocolitis may be related to the maturity of the gastrointestinal tract. We suggest that one important factor in gut maturity that relates to the risk of necrotizing enterocolitis may be diamine oxidase enzyme activity.

Acknowledgments. The authors thank Mr. Ken Cheeks for his expert assistance with the invertase assay and Ms. Lois Phillips for help in running the diamine oxidase assay. We also thank Ms. Peggy King for helping prepare this manuscript for publication.

\section{REFERENCES}

1. Santulli TV, Schullinger JN, Heird WC, Gongaware RD, Wigger J, Barlow B, Blanc WA, Berdon WE 1975 Acute necrotizing enterocolitis in infancy: a review of 64 cases. Pediatrics 55:376-387
2. Kusche J, Lorenz W, Stahlknecht CD, Richter H, Hesterberg R, Schmal A, Hinterlag E, Weber D, Ohmann C 1981 Intestinal diamine oxidase and histamine release in rabbit mesenteric ischemia. Gastroenterology 80:980 987

3. Bauer CR, Morrison JC, Poole WK, Korones SB, Boehm JJ, Rigatto H, Zachman RD 1984 A decreased incidence of necrotizing enterocolitis after prenatal glucocorticoid therapy. Pediatrics 73:682-688

4. Henning SJ 1986 Development of the gastrointestinal tract. Proc Nutr Soc 45:39-44

5. Martin GR, Henning SJ 1982 Relative importance of corticosterone and thyroxine in the postnatal development of sucrase and maltase in rat small intestine. Endocrinology 111:912-918

6. Thomas FB, Baba N, Greenberger NJ, Salsburey D 1972 Effect of phenobarbital on small intestinal structure and function in the rat. J Lab Clin Med 80:548-558

7. D'Agostino L, D'Argenio G, Ciacci C, Daniele B, Macchia V, Mazzacca G 1984 Diamine oxidase in rat small bowel: distribution in different segments and cellular location. Enzyme 31:217-220

8. Herbst JJ, Koldovsky O 1972 Cell migration and cortisone induction of sucrase activity in jejunum and ileum. Biochem $\mathrm{J}$ 126:471-476

9. Kusche J, Lorenz W 1983 Diamine oxidase. In: Bermeyer HU (ed) Methods of Enzymatic Analysis. Verlag Chemie, Basel, pp 237-250

10. Andersson AC, Henningsson S, Persson L, Rosengren E 1978 Aspects of diamine oxidase activity and its determination. Acta Physiol Scand 102:159166

11. Doell RG, Kretchmer N 1964 Intestinal invertase: precocious development of activity after injection of hydrocortisone. Science 143:42-44

12. Dahlquist A 1984 Alpha-glucosidases. In: Bermeyer HU (ed) Methods of Enzymatic Analysis. Verlag Chemie, Basel, pp 208-217

13. Lowry OH, Rosebrough NJ, Farr AL, Randall R 1951 Protein measurement with the Folin phenol reagent. J Biol Chem 193:265-275

14. Madsen AJ, Peter ET, Nicoloff DM, Walder AI, Wagensteen OH 1963 Histamine and mesenteric artery flow in the dog. JAMA 183:541-542

15. Kusche J, Stahlknecht CD, Lorenz W, Reichert G, Dietz W 1979 Comparison of alterations in the histamine-diamine oxidase system during acute intestinal ischaemia in pigs, dogs, and rabbits: evidence for a uniform pathophysiological mechanism. Agents Actions 9:49-52

16. Beaver MH, Wostmann BS 1962 Histamine and 5-hydroxytryptamine in the intestinal tract of germ-free animals, animals harbouring one microbial species and conventional animals. Br $J$ Pharmacol 19:385-393

17. Gaynes RP, Palmer S, Martone WJ, Holt CL, Buchter DS, Frawley LW, Perlino C, Kanto WP 1984 The role of host factors in an outbreak of necrotizing enterocolitis. Am J Dis Child 138:1118-1120

18. Wilson R, Kanto WP, McCarthy BJ, Burton A, Lewin P, Feldman RA 1982 Age at onset of necrotizing enterocolitis: an epidemiologic analysis. Pediatr Res 16:82-84 